\title{
The Level of Satisfaction in Health Service After Tooth Extraction in Puskesmas Polonia, Padang Bulan, Selayang II, Medan
}

\author{
Jelika Murni Sihombing \\ Student \\ Faculty of Dentistry \\ Universitas Sumatera Utara \\ Medan, Indonesia
}

\author{
Hendry Rusdy \\ Department of Oral and Maxillofacial Surgery \\ Faculty of Dentistry \\ Universitas Sumatera Utara \\ Medan, Indonesia
}

\begin{abstract}
Puskesmas is one of the most important public health service facilities in Indonesia. Tooth extraction is one of the dental clinic services provided in puskesmas. Tooth extraction is the process of removing a whole section of tooth along with its pathological tissue from the tooth socket and handling the complications that may occur. Patient satisfaction against dental care is a comparison between the perceptions and expectation before treatment. The study was conducted in Puskesmas Polonia, Padang Bulan, and Selayang II based on five dimensions of service quality using Likert scale. This is descriptive research with 146 samples selected by using accidental sampling method. Results showed that satisfaction of tooth extraction procedure were $66.6 \%$ in Puskesmas Polonia, 54.3\% in Puskesmas Padang Bulan, and $77.8 \%$ in Puskesmas Selayang II. In conclusion, the highest level of satisfaction in tooth extraction procedure was found in Puskesmas Selayang II with percentage of $\mathbf{7 7 . 8 \%}$.
\end{abstract}

\section{Keywords-patient satisfaction, extraction}

\section{INTRODUCTION}

Puskesmas is one of the most important public health services in Indonesia. Puskesmas is built to organize basic, comprehensive and integrated health service for the residents of its respective working area. Health programs organized by Puskesmas is the main program that must be implemented by the government to protect the population, which includes developing special programs for the poor [1]. One of the dental treatments in Puskesmas is tooth extraction. Tooth extraction is the process of removing all parts of the tooth together with its pathological tissue from the tooth socket and overcoming possible complications [2]. Dental and oral health services are integral part of health care to obtain insight, coverage and improvement in dental and oral health services. Based on UU No.36, 2009 , clause 93 about health, it is mentioned that dental and oral health services are conducted to maintain and improve the health status of the community by improving dental health services, provided by government, local government, and/or community in an integrated and sustainable way. Patient satisfaction is a positive evaluation of the different dimensions of health care [3]. Patient satisfaction is as important as other clinical health measurements and is the primary means of measuring the effectiveness of health services. Assessment of patient satisfaction is important, as it is not only determined by the quality of service, but also by patient expectations. Patient satisfaction is an imperfect measure that can be used to assess the quality of any service [4].

\section{MATERIALS AND METHODS}

This is descriptive survey to determine the level of patient satisfaction in tooth extraction procedure in Puskesmas Polonia, Puskesmas Padang Bulan, and Puskesmas Selayang II. The study was conducted at Puskesmas Polonia, Puskesmas Padang Bulan, and Puskesmas Selayang II from March to April 2017. The population is patients who came to the dental polyclinic for tooth extraction at Puskesmas Polonia, Padang Bulan, and Selayang II (accidental sampling). As many as 146 samples were selected for questionnaire filling.

\section{RESULTS}

The respondents in Puskesmas Polonia based on age group were classified as children aged 5-15 years old (6.3\%), adolescents aged 16-25 years old (12.5\%), adults aged 26-45 years old (25\%), the elders 46-65 years old $(50 \%)$, and the seniors aged $>66$ years old (6.3\%). The respondents in Puskesmas Padang Bulan based on age group were children aged 5-15 years old $(15.6 \%)$, adolescents aged 16-25 years old (17.3\%), adults aged $26-45$ years old $(26.6 \%)$, the elders aged 46-65 years old $(35.9 \%)$, and the seniors aged $>66$ years old (4.7\%). In Puskesmas Selayang II, respondents based on age group were children aged 515 years old $(20 \%)$, adolescents aged $16-25$ years old $(14 \%)$, adults aged $26-45$ years old $(30 \%)$, the elders $46-65$ years $(38 \%)$, the seniors aged > 66 years $(2 \%)$ (Table I). 
TABLE I. DISTRIBUTION OF RESPONDENTS IN PUSKESMAS POLONIA, PUSKESMAS PADANG BULAN, AND PUSKESMAS SELAYANG II BASED ON AGE

\begin{tabular}{|c|c|c|c|c|c|c|}
\hline \multirow{2}{*}{ Age (year) } & \multicolumn{2}{|c|}{$\begin{array}{c}\text { Puskesmas } \\
\text { Polonia }\end{array}$} & \multicolumn{2}{c|}{$\begin{array}{c}\text { Puskesmas } \\
\text { Padang } \\
\text { Bulan }\end{array}$} & \multicolumn{2}{c|}{$\begin{array}{c}\text { Puskesmas } \\
\text { Selayang } \\
\text { II }\end{array}$} \\
\cline { 2 - 7 } & $\boldsymbol{F}$ & $\mathbf{\%}$ & $\boldsymbol{F}$ & $\mathbf{\%}$ & $\boldsymbol{F}$ & $\%$ \\
\hline Children (5-15) & 2 & 6.3 & 10 & 15,6 & 10 & 20 \\
\hline Adolescents (16-25) & 4 & 12.5 & 11 & 17,3 & 7 & 14 \\
\hline Adults (26-35) & 8 & 25 & 17 & 26,6 & 15 & 30 \\
\hline Elders (36-45) & 16 & 50 & 23 & 35,9 & 19 & 38 \\
\hline Seniors (> 66) & 2 & 6.3 & 3 & 4,7 & 1 & 2 \\
\hline Total & 32 & 100 & 64 & 100 & 50 & 100 \\
\hline
\end{tabular}

Table II shows that distribution of respondents based on gender were $31.2 \%$ male and $68.8 \%$ female in Puskesmas Polonia, $37.5 \%$ male and $62.5 \%$ female in Puskesmas Padang Bulan, and 32\% male and 68\% female in Puskesmas Selayang II (Table II).

TABLE II. DISTRIBUTION OF RESPONDENTS IN PUSKESMAS POLONIA, PUSKESMAS PADANG BULAN, AND PUSKESMAS SELAYANG II BASED ON GENDER.

\begin{tabular}{|l|c|c|c|c|c|c|}
\hline \multirow{2}{*}{ Gender } & \multicolumn{2}{|c|}{$\begin{array}{c}\text { Puskesmas } \\
\text { Polonia }\end{array}$} & \multicolumn{2}{c|}{$\begin{array}{c}\text { Puskesmas } \\
\text { Padang Bulan }\end{array}$} & \multicolumn{2}{c|}{$\begin{array}{c}\text { Puskesmas } \\
\text { Selayang II }\end{array}$} \\
\cline { 2 - 7 } & $\boldsymbol{F}$ & $\boldsymbol{\%}$ & $\boldsymbol{F}$ & $\boldsymbol{\%}$ & $\boldsymbol{F}$ & \% \\
\hline Male & 10 & 31,2 & 24 & 37,5 & 16 & 32 \\
\hline Female & 22 & 68,8 & 40 & 62,5 & 34 & 68 \\
\hline Total & 32 & 100 & 64 & 100 & 50 & 100 \\
\hline
\end{tabular}

Table III shows distribution of respondents based on education level. The education level of respondents in Puskesmas Polonia were $6.3 \%$ without any formal education, $31.2 \%$ elementary school graduates, $12.5 \%$ junior high school graduates, $37.5 \%$ high school graduates, and $12.5 \%$ college graduates. In Puskesmas Padang Bulan, $18.6 \%$ respondents had no formal education, $14.1 \%$ were elementary school graduates, $7.8 \%$ were junior high school graduates, $32.8 \%$ were high school graduates, and $26.7 \%$ were college graduates. In Puskesmas Selayang II, 30\% respondents were found without any formal education, $16 \%$ were primary school graduates, $12 \%$ were junior high school graduates, $20 \%$ were high school graduates, and $22 \%$ were college graduates (Table III).

TABLE III. DISTRIBUTION OF RESPONDENTS IN PUSKESMAS POLONIA, PUSKESMAS PADANG BULAN, AND PUSKESMAS SELAYANG II BASED ON EDUCATION LEVEL

\begin{tabular}{|l|c|c|c|c|c|c|}
\hline \multicolumn{1}{|c|}{$\begin{array}{c}\text { Education } \\
\text { Level }\end{array}$} & \multicolumn{2}{|c|}{$\begin{array}{c}\text { Puskesmas } \\
\text { Polonia }\end{array}$} & \multicolumn{2}{c|}{$\begin{array}{c}\text { Puskesmas } \\
\text { Padang } \\
\text { Bulan }\end{array}$} & \multicolumn{2}{c|}{$\begin{array}{c}\text { Puskesmas } \\
\text { Selayang II }\end{array}$} \\
\cline { 2 - 7 } & $\boldsymbol{F}$ & $\%$ & $\boldsymbol{F}$ & $\%$ & $\boldsymbol{F}$ & $\%$ \\
\hline $\begin{array}{l}\text { No Formal } \\
\text { Education } \\
\text { Background }\end{array}$ & 2 & 6,3 & 12 & 18,6 & 15 & 30 \\
\hline $\begin{array}{l}\text { Elementary } \\
\text { Graduates }\end{array}$ & 10 & 31,2 & 9 & 14,1 & 8 & 16 \\
\hline $\begin{array}{l}\text { Junior High } \\
\text { School } \\
\text { Graduates }\end{array}$ & 4 & 12,5 & 5 & 7,8 & 6 & 12 \\
\hline $\begin{array}{l}\text { High School } \\
\text { Graduates }\end{array}$ & 12 & 37,5 & 21 & 32,8 & 10 & 20 \\
\hline $\begin{array}{l}\text { College } \\
\text { Graduates }\end{array}$ & 4 & 12,5 & 17 & 26,7 & 11 & 22 \\
\hline \multicolumn{1}{|c|}{ Total } & 32 & 100 & 64 & 100 & 50 & 100 \\
\hline
\end{tabular}

Based on occupation, the respondents in Puskesmas Polonia were consisted of $6.2 \%$ civil servants/army, $15.6 \%$ private employees/government employee, $18.8 \%$ entrepreneurs/traders, $6.2 \%$ retired, $34.4 \%$ housewives, and $18.8 \%$ students/unemployed. In Puskesmas Padang Bulan, respondents were consisted of $12.5 \%$ civil servants/army, $4.7 \%$ private employees/government employee, $25 \%$ entrepreneurs/traders, $6.2 \%$ retired, $36 \%$ housewives, and $15.6 \%$ students/unemployed. In Puskesmas Selayang II, $10 \%$ of respondents were civil servants/army, $4 \%$ were private employees/government employee, $28 \%$ were Entrepreneurs/traders, $10 \%$ were retired, $34 \%$ were housewives, and $14 \%$ students/unemployed (Table IV).

TABLE IV. DISTRIBUTION OF RESPONDENTS IN PUSKESMAS POLONIA, PUSKESMAS PADANG BULAN, AND PUSKESMAS SELAYANG II BASED ON OCCUPATION

\begin{tabular}{|l|c|c|c|c|c|c|}
\hline \multirow{2}{*}{ Occupation } & \multicolumn{2}{|c|}{$\begin{array}{c}\text { Puskesmas } \\
\text { Polonia }\end{array}$} & \multicolumn{2}{c|}{$\begin{array}{c}\text { Puskesmas } \\
\text { Padang } \\
\text { Bulan }\end{array}$} & \multicolumn{2}{c|}{$\begin{array}{c}\text { Puskesmas } \\
\text { Selayang II }\end{array}$} \\
\cline { 2 - 7 } & $\boldsymbol{F}$ & $\%$ & $\boldsymbol{F}$ & $\boldsymbol{\%}$ & $\boldsymbol{F}$ & $\%$ \\
\hline Army & 2 & 6.2 & 8 & 12.5 & 5 & 10 \\
\hline $\begin{array}{l}\text { Government } \\
\text { employee }\end{array}$ & 5 & 15.6 & 3 & 4.7 & 2 & 4 \\
\hline Entrepreneur & 6 & 18.8 & 16 & 25 & 14 & 28 \\
\hline Retired & 2 & 6.2 & 4 & 6.2 & 5 & 10 \\
\hline Housewife & 11 & 34.4 & 23 & 36 & 17 & 34 \\
\hline Student & 6 & 18.8 & 10 & 15.6 & 7 & 14 \\
\hline Total & 32 & 100 & 64 & 100 & 50 & 100 \\
\hline
\end{tabular}

Data of 32 respondents in Table $\mathrm{V}$ shows patient satisfaction level on dental and oral care in term of reliability in Puskesmas Polonia, which includes greeting $(68.7 \%)$, enquiring complaint $(68.7 \%)$, anamnesis $(68.7 \%)$, performing thorough examination $(71.8 \%)$, tool manipulation $(65.5 \%)$, and giving prescription (71.8\%). In Puskesmas Padang Bulan, the satisfaction level of 64 respondents in terms of reliability were $59.4 \%$ on greeting, $59.4 \%$ on enquiring complaint, $56.2 \%$ on anamnesis, $56.2 \%$ on thorough examination, $54.7 \%$ on tool manipulation, and $53.2 \%$ on giving prescription (Table VI). In Puskesmas Selayang II, the satisfaction level of 50 respondents in terms of reliability were $59.4 \%$ on greeting, $59.4 \%$ on enquiring complaint, $56.2 \%$ on anamnesis, $56.2 \%$ on thorough examination, $54.7 \%$ on tool manipulation, and $53.2 \%$ on giving prescription (Table VII).

TABLE V. PERCENTAGE OF PATIENT SATISFACTION IN TERMS OF RELIABILITY IN PUSKESMAS POLONIA

\begin{tabular}{|l|c|c|c|c|c|}
\hline \multirow{2}{*}{\multicolumn{1}{|c|}{ Reliability }} & \multicolumn{5}{c|}{ Puskesmas Polonia } \\
\cline { 2 - 6 } & $\boldsymbol{D S}$ & $\boldsymbol{L S}$ & $\boldsymbol{M S}$ & $\boldsymbol{S}$ & $\boldsymbol{V} \boldsymbol{S}$ \\
\hline Greeting & - & - & 2 & 22 & 8 \\
\hline Complaint enquiry & - & - & 6 & 22 & 4 \\
\hline Thorough examination & - & - & 2 & 22 & 8 \\
\hline Tool manipulation & - & - & 2 & 23 & 7 \\
\hline Post treatment instructions & - & - & 4 & 21 & 7 \\
\hline Giving prescription & - & - & 4 & 23 & 5 \\
\hline
\end{tabular}


TABLE VI. PERCENTAGE OF PATIENT SATISFACTION IN TERMS OF RELIABILITY IN PUSKESMAS PADANG BULAN

\begin{tabular}{|l|c|c|c|c|c|}
\hline \multirow{2}{*}{\multicolumn{1}{|c|}{ Reliability }} & \multicolumn{5}{c|}{ Puskesmas Padang Bulan } \\
\cline { 2 - 6 } & $\boldsymbol{D S}$ & $\boldsymbol{L S}$ & $\boldsymbol{M S}$ & $\boldsymbol{S}$ & $\boldsymbol{V} \boldsymbol{S}$ \\
\hline Greeting & - & - & 10 & 38 & 16 \\
\hline Complaint enquiry & - & - & 10 & 38 & 16 \\
\hline Thorough examination & - & 2 & 6 & 36 & 20 \\
\hline Tool manipulation & - & - & 9 & 36 & 19 \\
\hline Post treatment instructions & - & - & 8 & 35 & 21 \\
\hline Giving prescription & - & 1 & 9 & 34 & 20 \\
\hline
\end{tabular}

TABLE VII. PERCENTAGE OF PATIENT SATISFACTION IN TERMS OF RELIABILITY IN PUSKESMAS SELAYANG II.

\begin{tabular}{|l|c|c|c|c|c|}
\hline \multirow{2}{*}{\multicolumn{1}{|c|}{ Reliability }} & \multicolumn{5}{|c|}{ Puskesmas Selayang II } \\
\cline { 2 - 6 } & $\boldsymbol{D S}$ & $\boldsymbol{L S}$ & $\boldsymbol{M S}$ & $\boldsymbol{S}$ & $\boldsymbol{V S}$ \\
\hline Greeting & - & - & 5 & 35 & 10 \\
\hline Complaint enquiry & - & - & 3 & 35 & 12 \\
\hline Thorough examination & - & - & 2 & 38 & 10 \\
\hline Tool manipulation & - & - & 2 & 37 & 11 \\
\hline Post treatment instructions & - & - & 5 & 36 & 9 \\
\hline Giving prescription & - & - & 3 & 36 & 11 \\
\hline
\end{tabular}

Data in Table VIII shows patient satisfaction level on dental and oral care in term of service in Puskesmas Polonia, which includes accurate management of complaint $(62.5 \%, 65.6 \%$, and $68.7 \%)$, enquiry of patient's condition (65.6\%), ability to relieve complaint (71.8\%), and short waiting time (62.5\%). In Puskesmas Padang Bulan, patient satisfaction levels were 50\%, $51.7 \%, 46.9 \%$ on accurate management, $53.1 \%$ on enquiry of patient's condition, $48.4 \%$ on ability to relieve complaint, and $45.3 \%$ on short waiting time (Table IX). In Puskesmas Selayang II, patient satisfaction levels were $76 \%, 80 \%$ on accurate management, $78 \%$ on enquiry of patient's condition, $80 \%$ on ability to relieve complaint, and $76 \%$ on short waiting time (Table $\mathrm{X}$ ).

TABLE VIII. PERCENTAGE OF PATIENT SATISFACTION IN TERMS OF ADEPT SERVICE IN PUSKESMAS POLONIA

\begin{tabular}{|l|c|c|c|c|c|}
\hline \multirow{2}{*}{\multicolumn{1}{c|}{ Adept Service }} & \multicolumn{5}{|c|}{ Puskesmas Polonia } \\
\cline { 2 - 6 } & $\boldsymbol{D S}$ & $\boldsymbol{L S}$ & $\boldsymbol{M S}$ & $\boldsymbol{S}$ & $\boldsymbol{V S}$ \\
\hline Accurate management & - & - & 1 & 20 & 11 \\
\hline Enquiry of condition & - & - & 2 & 21 & 9 \\
\hline Dentist response & - & - & 1 & 22 & 9 \\
\hline Skill & - & - & - & 23 & 9 \\
\hline Appropriate handling & - & - & 1 & 21 & 10 \\
\hline Short waiting time & - & - & 1 & 20 & 11 \\
\hline
\end{tabular}

TABLE IX. PERCENTAGE OF PATIENT SATISFACTION IN TERMS OF ADEPT SERVICE IN PUSKESMAS POLONIA

\begin{tabular}{|l|c|c|c|c|c|}
\hline \multirow{2}{*}{\multicolumn{1}{|c|}{ Adept Service }} & \multicolumn{5}{|c|}{ Puskesmas Padang Bulan } \\
\cline { 2 - 7 } & $\boldsymbol{D S}$ & $\boldsymbol{L S}$ & $\boldsymbol{M S}$ & $\boldsymbol{S}$ & $\boldsymbol{V} \boldsymbol{S}$ \\
\hline Accurate management & - & - & 7 & 32 & 25 \\
\hline Enquiry of condition & - & - & 9 & 34 & 21 \\
\hline Dentist response & - & 1 & 10 & 33 & 21 \\
\hline Skill & - & 1 & 9 & 31 & 23 \\
\hline Appropriate handling & - & - & 9 & 30 & 25 \\
\hline Short waiting time & 1 & - & 9 & 29 & 25 \\
\hline
\end{tabular}

TABLE X. PERCENTAGE OF PATIENT SATISFACTION IN TERMS OF ADEPT SERVICE PUSKESMAS SELAYANG II

\begin{tabular}{|l|c|c|c|c|c|}
\hline \multirow{2}{*}{\multicolumn{1}{|c|}{ Adept Service }} & \multicolumn{5}{|c|}{ Puskesmas Selayang II } \\
\cline { 2 - 6 } & $\boldsymbol{D S}$ & $\boldsymbol{L S}$ & $\boldsymbol{M S}$ & $\boldsymbol{S}$ & $\boldsymbol{V S}$ \\
\hline Accurate management & - & - & 3 & 38 & 9 \\
\hline Enquiry of condition & - & - & 1 & 39 & 10 \\
\hline Dentist response & - & - & 3 & 40 & 7 \\
\hline Skill & - & - & 1 & 40 & 9 \\
\hline Appropriate handling & - & - & 1 & 40 & 9 \\
\hline Short waiting time & - & - & 3 & 38 & 9 \\
\hline
\end{tabular}

Data in Table XI shows patient satisfaction level on dental and oral care in term of empathy in Puskesmas Polonia, including careful handling (68.7\%), understanding $(65.6 \%)$, concern $(65.6 \%)$, impartiality $(68.7 \%)$, patience $(62.5 \%)$, and friendliness $(65.6 \%)$. In Puskesmas Padang Bulan, the patient satisfaction levels were $51.7 \%$ on careful handling, $59.4 \%$ on understanding, $62.5 \%$ on concern, $51.7 \%$ on impartiality, $56.2 \%$ on patience, and $46.9 \%$ on friendliness (Table XII). In Puskesmas Selayang II, the patient satisfaction levels were $76 \%$ on careful handling, $78 \%$ on understanding, $80 \%$ on concern, $86 \%$ on impartiality, $80 \%$ on patience, and $78 \%$ on friendliness (Table XIII).

TABLE XI. PERCENTAGE OF PATIENT SATISFACTION IN TERMS OF EMPATHY IN PUSKESMAS POLONIA

\begin{tabular}{|l|c|c|c|c|c|}
\hline \multirow{2}{*}{\multicolumn{1}{|c|}{ Empathy }} & \multicolumn{5}{c|}{ Puskesmas Polonia } \\
\cline { 2 - 6 } & $\boldsymbol{D S}$ & $\boldsymbol{L S}$ & $\boldsymbol{M S}$ & $\boldsymbol{S}$ & $\boldsymbol{V S}$ \\
\hline Careful handling & - & - & 3 & 22 & 7 \\
\hline Understanding & - & - & 3 & 21 & 8 \\
\hline Concern & - & - & 3 & 21 & 7 \\
\hline Impartiality & - & - & 1 & 22 & 9 \\
\hline Patience & - & - & 2 & 20 & 10 \\
\hline Friendliness & - & - & 1 & 21 & 10 \\
\hline
\end{tabular}

TABLE XII. PERCENTAGE OF PATIENT SATISFACTION IN TERMS OF EMPATHY IN PUSKESMAS PADANG BULAN

\begin{tabular}{|l|c|c|c|c|c|}
\hline \multirow{2}{*}{\multicolumn{1}{|c|}{ Empathy }} & \multicolumn{5}{|c|}{ Puskesmas Padang Bulan } \\
\cline { 2 - 6 } & $\boldsymbol{D S}$ & $\boldsymbol{L} \boldsymbol{S}$ & $\boldsymbol{M S}$ & $\boldsymbol{S}$ & $\boldsymbol{V} \boldsymbol{S}$ \\
\hline Careful handling & - & - & 8 & 33 & 20 \\
\hline Understanding & - & - & 5 & 38 & 21 \\
\hline Concern & - & - & 7 & 40 & 20 \\
\hline Impartiality & - & - & 7 & 33 & 25 \\
\hline Patience & - & - & 7 & 36 & 22 \\
\hline Friendliness & - & - & 7 & 30 & 28 \\
\hline
\end{tabular}

TABLE XIII. PERCENTAGE OF PATIENT SATISFACTION IN TERMS OF EMPATHY IN PUSKESMAS SELAYANG II

\begin{tabular}{|l|c|c|c|c|c|}
\hline \multirow{2}{*}{\multicolumn{1}{|c|}{ Empathy }} & \multicolumn{5}{c|}{ Puskesmas Selayang II } \\
\cline { 2 - 6 } & $\boldsymbol{D S}$ & $\boldsymbol{L S}$ & $\boldsymbol{M S}$ & $\boldsymbol{S}$ & $\boldsymbol{V S}$ \\
\hline Careful handling & - & - & 3 & 38 & 9 \\
\hline Understanding & - & - & 3 & 40 & 7 \\
\hline Concern & - & - & 3 & 39 & 8 \\
\hline Impartiality & - & - & - & 43 & 7 \\
\hline Patience & - & - & - & 40 & 10 \\
\hline Friendliness & - & - & - & 39 & 11 \\
\hline
\end{tabular}

Table XIV shows patient satisfaction level in term of service assurance in Puskesmas Polonia, including doubtless handling (75\%), convincing patient $(71.9 \%)$, providing clear explanation $(65.6 \%)$, certainty $(68.7 \%)$, working with assistance $(68.7 \%)$, and confidentiality (62.5\%). In Puskesmas Padang Bulan, patient 
satisfaction levels on service assurance were $56.2 \%$ on doubtless handling, $59.3 \%$ on convincing patient, $57.8 \%$ on clear explanation, $56.2 \%$ on certainty, $56.2 \%$ on working with assistance, and $67.2 \%$ on confidentiality (Table XV). In Puskesmas Selayang II, patient satisfaction levels on service assurance were $80 \%$ on doubtless handling, $78 \%$ on convincing patient, $82 \%$ on clear explanation, $74 \%$ on certainty, $80 \%$ on working with assistance, and $80 \%$ on confidentiality (table XVI).

TABLE XIV. PERCENTAGE OF PATIENT SATISFACTION IN TERMS OF SERVICE ASSURANCE IN PUSKESMAS POLONIA

\begin{tabular}{|l|c|c|c|c|c|}
\hline \multirow{2}{*}{\multicolumn{1}{|c|}{ Assurance }} & \multicolumn{5}{|c|}{ Puskesmas Polonia } \\
\cline { 2 - 6 } & $\boldsymbol{D S}$ & $\boldsymbol{L S}$ & $\boldsymbol{M S}$ & $\boldsymbol{S}$ & $\boldsymbol{V S}$ \\
\hline Doubtless handling & - & - & - & 24 & 8 \\
\hline Convincing & - & - & - & 23 & 9 \\
\hline Clear explanation & - & - & 3 & 21 & 8 \\
\hline Certainty & - & - & 2 & 22 & 8 \\
\hline Assistance & - & - & - & 22 & 10 \\
\hline Confidentiality & - & - & 4 & 20 & 7 \\
\hline
\end{tabular}

TABLE XV. PERCENTAGE OF PATIENT SATISFACTION IN TERMS OF SERVICE ASSURANCE IN PUSKESMAS PADANG BULAN

\begin{tabular}{|l|c|c|c|c|c|}
\hline \multirow{2}{*}{\multicolumn{1}{|c|}{ Assurance }} & \multicolumn{5}{c|}{ Puskesmas Padang Bulan } \\
\cline { 2 - 6 } & $\boldsymbol{D S}$ & $\boldsymbol{L S}$ & $\boldsymbol{M S}$ & $\boldsymbol{S}$ & $\boldsymbol{V S}$ \\
\hline Doubtless handling & - & - & 5 & 36 & 23 \\
\hline Convincing & - & - & 4 & 38 & 22 \\
\hline Clear explanation & - & - & 10 & 37 & 17 \\
\hline Certainty & - & - & 8 & 36 & 20 \\
\hline Assistance & - & - & 10 & 36 & 18 \\
\hline Confidentiality & - & - & 5 & 43 & 16 \\
\hline
\end{tabular}

TABLE XVI. PERCENTAGE OF PATIENT SATISFACTION IN TERMS OF SERVICE ASSURANCE IN PUSKESMAS SELAYANG II

\begin{tabular}{|l|c|c|c|c|c|}
\hline \multirow{2}{*}{\multicolumn{1}{|c|}{ Assurance }} & \multicolumn{5}{c|}{ Puskesmas Selayang II } \\
\cline { 2 - 6 } & $\boldsymbol{D S}$ & $\boldsymbol{L S}$ & $\boldsymbol{M S}$ & $\boldsymbol{S}$ & $\boldsymbol{V S}$ \\
\hline Doubtless handling & - & - & - & 40 & 10 \\
\hline Convincing & - & - & 2 & 39 & 9 \\
\hline Clear explanation & - & - & 1 & 41 & 8 \\
\hline Certainty & - & - & 1 & 37 & 12 \\
\hline Assistance & - & - & 2 & 40 & 8 \\
\hline Confidentiality & - & - & 1 & 40 & 9 \\
\hline
\end{tabular}

Table XVII shows patient satisfaction level in term of physical performance in Puskesmas Polonia, including clean and comfortable room $(62.5 \%)$, decent dental unit $(71.8 \%)$, dentist's appearance $(59.3 \%)$, sterile tools $(71.8 \%)$, use of gloves $(59.3 \%)$, and handwashing prior to treatment (56.2\%). In Puskesmas Padang Bulan, patient satisfaction levels in term of physical appearance were $53.1 \%$ on clean and comfortable room, $45.3 \%$ on decent dental unit, $46.9 \%$ on dentist's appearance, $54.7 \%$ on sterile tools, $50 \%$ on use of gloves, and $54.7 \%$ on hand-washing prior to treatment (Table XVIII). In Puskesmas Selayang II, patient satisfaction levels in term of physical appearance were $78 \%$ on clean and comfortable room, $80 \%$ on decent dental unit, $76 \%$ on dentist's appearance, $80 \%$ on sterile tools, $84 \%$ on use of gloves, and $82 \%$ on hand-washing prior to treatment (Table XIX).
TABLE XVII. PERCENTAGE OF PATIENT SATISFACTION IN TERMS OF PHYSICAL PERFORMANCE IN PUSKESMAS POLONIA

\begin{tabular}{|l|c|c|c|c|c|}
\hline \multirow{2}{*}{\multicolumn{1}{c|}{ Physical Appearance }} & \multicolumn{5}{c|}{ Puskesmas Polonia } \\
\cline { 2 - 7 } & $\boldsymbol{D S}$ & $\boldsymbol{L S}$ & $\boldsymbol{M S}$ & $\boldsymbol{S}$ & $\boldsymbol{V} \boldsymbol{S}$ \\
\hline Clean and comfortable room & - & - & 3 & 20 & 9 \\
\hline Decent dental unit & - & - & 2 & 23 & 7 \\
\hline Dentist's appearance & - & - & 4 & 19 & 9 \\
\hline Sterile tools & - & - & 1 & 23 & 8 \\
\hline Use of gloves & - & - & 1 & 19 & 11 \\
\hline Hand-washing prior to treatment & - & - & 5 & 18 & 9 \\
\hline
\end{tabular}

TABLE XVIII. PERCENTAGE OF PATIENT SATISFACTION IN TERMS OF PHYSICAL PERFORMANCE IN PUSKESMAS PADANG BULAN

\begin{tabular}{|l|c|c|c|c|c|}
\hline \multirow{2}{*}{\multicolumn{1}{c|}{ Physical Appearance }} & \multicolumn{5}{c|}{ Puskesmas Padang Bulan } \\
\cline { 2 - 7 } & $\boldsymbol{D S}$ & $\boldsymbol{L S}$ & $\boldsymbol{M S}$ & $\boldsymbol{S}$ & $\boldsymbol{V S}$ \\
\hline Clean and comfortable room & - & 1 & 4 & 34 & 25 \\
\hline Decent dental unit & - & 1 & 3 & 29 & 31 \\
\hline Dentist's appearance & - & - & 4 & 30 & 30 \\
\hline Sterile tools & - & - & 7 & 35 & 22 \\
\hline Use of gloves & - & - & 6 & 32 & 26 \\
\hline Hand-washing prior to treatment & - & - & 6 & 35 & 23 \\
\hline
\end{tabular}

TABLE XIX. PERCENTAGE OF PATIENT SATISFACTION IN TERMS OF PHYSICAL PERFORMANCE IN PUSKESMAS SELAYANG

\begin{tabular}{|l|c|c|c|c|c|}
\hline \multirow{2}{*}{\multicolumn{1}{c}{ Physical Appearance }} & \multicolumn{5}{c|}{ Puskesmas Selayang II } \\
\cline { 2 - 6 } & $\boldsymbol{D S}$ & $\boldsymbol{L S}$ & $\boldsymbol{M S}$ & $\boldsymbol{S}$ & $\boldsymbol{V S}$ \\
\hline Clean and comfortable room & - & 1 & 1 & 39 & 9 \\
\hline Decent dental unit & - & 1 & 3 & 40 & 6 \\
\hline Dentist's appearance & - & - & 1 & 38 & 11 \\
\hline Sterile tools & 1 & - & 1 & 40 & 8 \\
\hline Use of gloves & - & - & 1 & 42 & 7 \\
\hline Hand-washing prior to treatment & - & - & - & 41 & 9 \\
\hline
\end{tabular}

The overall patient satisfaction levels on tooth extraction management were $66.6 \%$ in Puskesmas Polonia, 54.3\% in Puskesmas Padang Bulan, and 77.8\% in Puskesmas Selayang II. In conclusion, the highest level of satisfaction was found in Puskesmas Selayang II.

\section{DISCUSSION}

Patient satisfaction is the condition when the patient's wishes, hopes and needs are met. The results show that more female patients received dental and oral care, which were $68.8 \%$ in Puskesmas Polonia women, $62.5 \%$ in Puskesmas Padang Bulan, and 68.85 in Puskesmas Selayang II. This is in accordance with research of Annisaa Yuniar Azhari (2013) where women are easily satisfied with dental and mouth care, so majority of patients are women [5].

The most patients in Puskesmas Polonia were in age group of 46-55 year old (31.2\%), in Puskesmas Padang Bulan were 56-65 years old (25\%), and in Puskesmas Selayang II were $56-65$ years old $(22 \%)$. This is different from other studies, possibly due to majority of elderly patients who wanted to make dentures, so special care in handling tooth extraction were needed. The most common education level of patients in Puskesmas Polonia was high school graduate (12 person, $37.5 \%$ ) and the least was patients with no formal education (2 person, 6.3\%); in Puskesmas Padang Bulan, the most common found patients were high school graduates (21 person, 32.8\%) and the least 
was junior high school graduates (5 person, $7.8 \%$ ); in Puskesmas Selayang II, the most common patients had no formal education (15 person, 30\%) and the least were junior high school graduates (6 person, $12 \%)$. This is in accordance with the study of Annisa Yuniar Azhari 2013 which showed that patients with lower education level tended to be satisfied quickly.

Based on occupation, the most common patients of the three Puskesmas are housewives, 11 person (34.4) in Puskesmas Polonia $(34,4 \%), 23$ person $(36 \%)$ in Puskesmas Padang, and 17 person (34\%) Puskesmas Selayang II. This result is supported by the study of Yaya Priatna Jalimun which stated that non-civil servants are more common in the community, and they spend their spare time to have dental examination at the Puskesmas [6].

The overall satisfaction level in term of reliability in the three Puskesmas was categorized as satisfied with mean value of $66 \%$. This is consistent to the study of Mariane et al (2014) which showed 84.6 index of satisfaction [7].

Patient satisfaction level in term of adept service was categorized as satisfied with mean value of $64.4 \%$. This is consistent to the study of Andi Ika Anggraini (2015), with result of $60 \%$ in satisfaction category. It shows that, in this study, patients were satisfied with dentist's ability in management of complaints and procedure of extraction [8].

In terms of empathy, the mean value of satisfaction level was $67.3 \%$, categorized as satisfied. It shows that patients were satisfied the care given by dentists in minimizing anxiety of patients. This is consistent to the study of Ristoria Simbolon (2011) showing that patient satisfaction level on empathy was $66.7 \%$ [4].

In terms of adept service, the mean value of satisfaction level was $64.4 \%$. It shows that patients were satisfied the information given by dentists regarding complaints. This is consistent to the study of Gita Putri
Kencana (2016) showing that patient satisfaction level on adept service was $71 \%$ [9].

One of the respondents in Puskesmas Padang Bulan expressed dissatisfaction on short waiting time. This was due to a long queue of patients, which happened as three dentists and a dental nurse were not available on regular basis.

In term of physical performance, the mean value of satisfaction level was $64.7 \%$. This is consistent to the study of Mariane et al (2014) which showed $80.7 \%$ satisfaction level on physical performance [6]. This proves that patients were satisfied with the facilities available in the three Puskesmas.

\section{REFERENCES}

[1] Muninjaya, A.A. Gde, Manajemen mutu pelayanan kesehatan, Jakarta: EGC, 2011, pp. 8-16.

[2] C. Kristanti, M.D. Hapsari, Kesenjangan antara kebutuhan dan kemampuan untuk mendapatkan perawatan gigi, Need And Demand for Dental Treatment: Riskesdas, 2007, pp.1155-1165.

[3] G.D. Kang, J. James, "Service quality dimensions: An examination of gronroos service quality model," vol. 14, pp. 266-277, 2006

[4] R. Simbolon, Tingkat Kepuasan Pasien Terhadap Pelayanan Kesehatan Gigi dan Mulut di RSUD DR. Djasamen Saragih Pematangsiantar, Sumatera Utara, Skripsi, Medan: Fakultas Kedokteran Gigi Universitas Sumatera Utara, 2011, pp. 1-19.

[5] A.Y. Azhari, Tingkat kepuasan pasien pasca pencabutan gigi di RSGMP Kandea FKG UH tahun 2013, Skripsi, Makassar: Universitas Hasanuddin, 2013, pp. 53.

[6] Y.P. Jalimun, "Kepuasan pasien di balai pengobatan gigi Puskesmas Kahuripan Kota Tasikmalaya," J Kesehatan Komunitas Indonesia, vol. 10, pp. 3-15, 2014.

[7] M. Sembel, H. Opod, S.P. Bernart, "Gambaran Tingkat kepuasan pasien terhadap perawatan gigi dan mulut di Puskesmas Bahu,” Jurnal e-Gigi, vol. 2, pp. 1-10, 2014.

[8] A.I. Anggraini, Kepuasan pasien terhadap mutu Pelayanan Kesehatan gigi di poliklinik gigi dan mulut Rumah Sakit Umum Daerah (RSUD) Tenriawaru Kabupaten Bone, Skripsi, Makassar: Universitas Hasanuddin, 2015, pp. 31.

[9] G.P. Kencana, Tingkat kepuasan pasien terhadap Pencabutan gigi oleh mahasiswa profesi di klinik bedah mulut RSGMP Universitas Jember, Skripsi, Jember: Universitas Jember, 2016, pp. 49. 